\title{
Brain transcriptome variation among behaviorally distinct strains of zebrafish (Danio rerio)
}

\author{
Robert E Drew ${ }^{1,2 \dagger}{ }^{1}$, Matthew L Settles ${ }^{3}$, Erin J Churchill', Shayna M Williams ${ }^{1}$, Soniya Balli ${ }^{2}$ and Barrie D Robison ${ }^{1 *+}$
}

\begin{abstract}
Background: Domesticated animal populations often show profound reductions in predator avoidance and fearrelated behavior compared to wild populations. These reductions are remarkably consistent and have been observed in a diverse array of taxa including fish, birds, and mammals. Experiments conducted in common environments indicate that these behavioral differences have a genetic basis. In this study, we quantified differences in fear-related behavior between wild and domesticated zebrafish strains and used microarray analysis to identify genes that may be associated with this variation.

Results: Compared to wild zebrafish, domesticated zebrafish spent more time near the water surface and were more likely to occupy the front of the aquarium nearest a human observer. Microarray analysis of the brain transcriptome identified high levels of population variation in gene expression, with 1,749 genes significantly differentially expressed among populations. Genes that varied among populations belonged to functional categories that included DNA repair, DNA photolyase activity, response to light stimulus, neuron development and axon guidance, cell death, iron-binding, chromatin reorganization, and homeobox genes. Comparatively fewer genes (112) differed between domesticated and wild strains with notable genes including gpr177 (wntless), selenoprotein P1a, synaptophysin and synaptoporin, and acyl-CoA binding domain containing proteins (acbd3 and acbd4).

Conclusions: Microarray analysis identified a large number of genes that differed among zebrafish populations and may underlie behavioral domestication. Comparisons with similar microarray studies of domestication in rainbow trout and canids identified sixteen evolutionarily or functionally related genes that may represent components of shared molecular mechanisms underlying convergent behavioral evolution during vertebrate domestication. However, this conclusion must be tempered by limitations associated with comparisons among microarray studies and the low level of population-level replication inherent to these studies.
\end{abstract}

Keywords: Zebrafish, Transcriptome, Microarray, Behavior, Anxiety, Domestication

\section{Background}

The process of animal domestication is a striking example of convergent behavioral evolution. During domestication, populations diverge from their wild progenitors as a result of genetic drift, artificial selection on desirable traits, relaxed selection on previously important characteristics, and adaptation to new environmental and ecological conditions [1-3]. Evolution in captivity is associated with a set of phenotypic changes,

\footnotetext{
* Correspondence: brobison@uidaho.edu

${ }^{\dagger}$ Equal contributors

${ }^{1}$ Department of Biological Sciences and Program in Bioinformatics and Computational Biology, University of Idaho, Moscow, ID 83844, USA Full list of author information is available at the end of the article
}

including enhanced growth rate [4-6], attenuated responsiveness to stress $[7,8]$, increased feeding behavior [9], and reduced predator avoidance behavior $[6,10,11]$. Reductions in predator avoidance behavior are the most consistent responses to domestication and have been observed across a broad range of taxa, including mammals, birds, and fish [12-14]. However, it is not known whether the apparent convergent evolution of predator avoidance behavior during domestication is the result of similar genetic changes or of changes in a myriad of alternative molecular "routes" to the same phenotypic endpoint. In fact, little is known about the genetic polymorphisms associated with domestication in any vertebrate species.

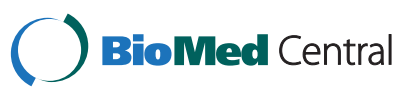


Differences in gene regulation are an important source of genetic variation for phenotypic evolution [15-17]. Transcriptome analyses have detected substantial variation among populations in numerous species, including yeast [18], Drosophila [19], fish [17,20-24], and humans $[25,26]$. Much of this variation has a heritable component [25,27-30]. While the majority of variation in gene expression appears to evolve in a neutral fashion, some genes show patterns consistent with evolution under positive selection and may contribute to local adaptation [17,29,31-33], including behavioral adaptations [20,34]. In particular, microarray studies suggest that domestication may also be associated with changes in gene expression [22,35-37].

In the present study, we use the zebrafish (Danio rerio) as a model for examining the relationship between behavioral domestication and variation in gene expression. The utility of the zebrafish in developmental biology and genomics is widely known, and there has been increased usage of the zebrafish as a model for behavior genetics [38-41]. Variation in behavior has been observed among populations of zebrafish, including variation among domesticated (laboratory) populations [38], among populations recently acquired from the wild [42], and between wild and domesticated populations [9,43-45]. In each of these studies, the populations were reared under identical conditions suggesting that the differences in behavior have a genetic component $[9,43,44]$.

In our study, we used microarrays to perform a transcriptome-wide analysis of variation in brain gene expression among four behaviorally distinct strains of zebrafish with different histories of domestication. First, we quantified behavioral differences between wild and domesticated zebrafish strains using a high throughput behavior assay [46]. Second, using microarrays, we detected substantial variation in expression profiles among these behaviorally distinct populations, a portion of which was associated with domestication history. Finally we compared our results against other microarray studies $[22,35-37,47]$ and identified sixteen homologous genes that were associated with behavioral domestication and variation in fear-related behavior across multiple species.

\section{Results and discussion}

\section{Behavioral variation among zebrafish strains}

We used a simple, high-throughput assay to characterize behavioral differences among zebrafish strains [46]. The assay was based on initial observations that fish from domesticated strains tended to spend more time near the surface and at the front of the aquarium nearest human technicians while wild fish tended to be found at the back and near the bottom of the aquarium. This assay decomposes this place preference type behavior into a vertical component (Vertical Depth) and a horizontal component (Horizontal Position). Vertical Depth quantifies the mean distance of an individual from the water surface while Horizontal Position is the proportion of the time an individual spends within one body length of the front of the tank, nearest to a human observer.

Although simple in design, the behaviors quantified by this assay can be used as indices of fear-related behavior in fish species, and are likely indicators of trade-offs between foraging and predator avoidance. In the wild, proximity to the surface is believed to increase the risk of predation by aerial predators $[13,48,49]$ and observations of zebrafish and other fish species are consistent with this hypothesis [50,51]. However, in captivity, fish are commonly offered food that floats on the surface, providing a contradictory stimulus for approaching the surface. Indeed, mean distance from the surface is negatively correlated with feeding behavior in zebrafish (M. Oswald and B.D.R., Unpublished data), masu salmon (O. masou) [52], and growth hormone transgenic coho salmon (O. kisutch) [53]. Also distance from the surface is positively correlated with freezing in response to a simulated predator by masu salmon [52]. Recent work has also shown that zebrafish spend less time in the upper half of aquaria in response to stressful stimuli and treatment with anxiogenic chemicals (alarm pheromone and caffeine), and more time following treatment with anxiolytic compounds (ethanol and fluoxetine) [54]. Therefore we conclude that these behaviors are valid indicators of fearfulness in various fish species.

We used these behavior assays to characterize four strains of zebrafish with different histories of domestication. The Scientific Hatcheries and Transgenic Mosaic 1 (TM1) strains have been reared in the laboratory for at least 30 generations and will be referred to as "domesticated." The Gaighata and Nadia strains were recently acquired from wild populations in India and, at the time of this study, had been reared in captivity for 1 and 6 generations, respectively. For the sake of brevity, these strains will be referred to as "wild." Although all of the fish used in this experiment were bred and reared under identical captive conditions ("common garden"), there were significant behavioral differences between wild and domesticated zebrafish strains. The wild strains spent markedly less time within one body length of the front of the aquarium, nearest the observer (low Horizontal Position, $\mathrm{F}=208.45, \mathrm{df}=3,58, P<0.0001$ ), and showed a greater preference for the lower portions of the water column (greater Vertical Depth, $\mathrm{F}=25.46$, $\mathrm{df}=3,58$, $P<0.0001$ ) than the domesticated strains (Figure 1).

The differences in behavior between wild and domesticated zebrafish populations were consistent with previous observations of these and other strains of zebrafish $[9,43-$ 45]. In particular, these four strains vary in their latency 


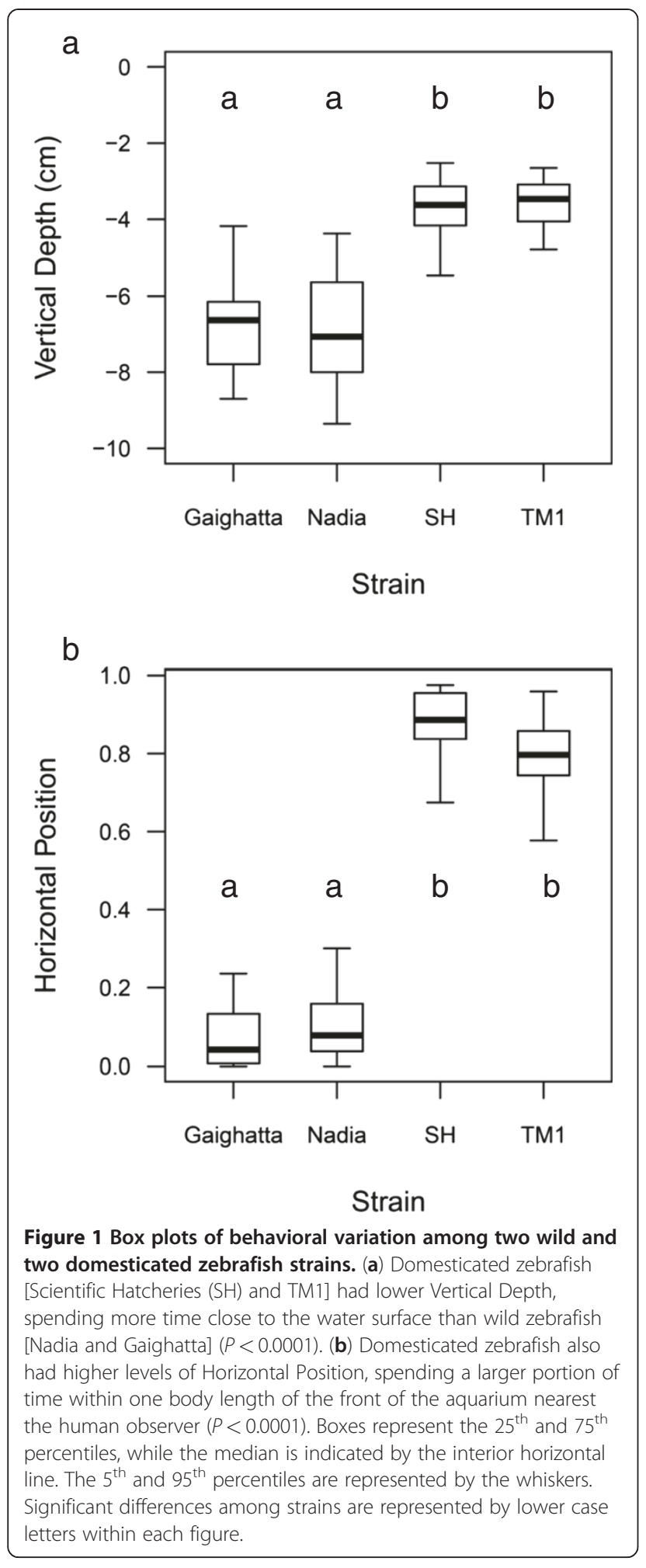

to feed from the surface of the water such that wild fish take much longer to commence feeding than domesticated fish [9]. Likewise, similar differences have been observed between wild and domesticated populations of other fish species (primarily salmonids) [13,48,55-59]. In general, domesticated fish tend to be bolder, feed more frequently, and have reduced ability to avoid predation [13], characteristics that have been linked with decreased survival in a wild environment [60].

\section{Transcriptome variation among zebrafish strains}

We next tested if these behaviorally distinct zebrafish strains also differed in gene expression in the brain to identify genes or pathways that may underlie behavioral variation. GeneChip ${ }^{\circledR}$ Zebrafish Genome microarrays (Affymetrix, Santa Clara, CA) were used to quantify the expression of approximately 14,900 zebrafish transcripts in the brains of fish observed in the behavior study above.

A total of 7,958 probe sets were detected as expressed in our zebrafish brain samples, based on our filtering criteria for expression (see Methods). Of these, 3,199 probe sets displayed probe level variation indicative of sequence polymorphisms among individuals and populations, known as single feature polymorphisms (SFPs) [61-63]. The presence of SFPs can confound comparisons of gene expression among different genotypes and therefore these features were removed from the analysis.

The remaining 4,759 probe sets were analyzed using linear models for microarrays (limma) [64,65] to test for differences in transcriptome profiles among strains, between wild and domesticated strains, and between males and females. Our initial analysis revealed considerable variation in gene expression among the strains with 1,752 probe sets differentially expressed among strains, 259 with a 2-fold or greater difference in pairwise comparisons of mean expression levels [see Additional file 1]. This level of brain transcriptome variation among populations is substantially higher that than observed between two populations of rainbow trout (201 genes, [37]) and among eight behaviorally diverse inbred mouse lines (188 genes, [47]); however these differences may reflect differences in statistical analyses or gene content of the array platforms.

The three probe sets with the highest differences among strains corresponded to quality control probe sets for green fluorescent protein (GFP: AFFX-Dr-M626531_at, AFFX-Dr-M62653-1_s_at) and cyan fluorescent protein (CFP: AFFX-Dr-AF292560-1_s_at). Because the expression of GFP in the TM1 strain was the result of transgenic manipulation [66], these genes were removed from the analysis. The next ten most differentially expressed zebrafish genes included cytochrome P450, family 1 , subfamily A (cyp1a); major histocompatibility complex class II DAB gene $(m h c 2 d a b)$; G proteincoupled receptor 177 (gpr177); and seven unannotated sequences.

The Database for Annotation, Visualization and Integrated Discovery (DAVID version 6.7) $[67,68]$ was used 
to identify functional categories that were overrepresented in the final gene lists (excluding SFPs) relative to the 7,958 genes detected as expressed in our analysis. DAVID identified 116 functional categories that were significantly overrepresented among genes that varied in expression among strains [see Additional file 2]. Notable functional categories included those involved in DNA repair, DNA photolyase activity, response to light stimulus, neuron development and axon guidance, cell death, iron-binding, WD40 repeat domains, chromatin organization, and homeobox genes. Functional interpretation of these findings is complicated because, although these genes differed among zebrafish populations, variation in expression was distributed in different patterns among the four zebrafish populations and did not necessarily involve correlated expression. These categories may represent functional groups of genes that, in the brain, may frequently vary among zebrafish populations. It is not known if this variation in gene expression is under selection or whether it is associated with variation in brain function or behavior.

\section{Transcriptome variation between wild and domesticated strains}

A total of 612 probe sets were initially identified as differentially expressed between wild and domesticated strains. Visual inspection of the data suggested that many of these differences were driven by extreme values in one of the strains. To increase the stringency of the analysis, genes associated with domestication were retained if the ranges of expression levels of wild and domesticated samples overlapped by no more than one sample. This additional criterion narrowed the list to 112 genes that were differentially expressed between wild and domesticated samples, 10 of which had a 2-fold difference or greater [see Additional file 3].

G protein-coupled receptor 177 (gpr177) showed the largest difference with a 5.59-fold down-regulation in domesticated zebrafish. gpr177, also known as wntless or evenness interrupted (evi), is necessary for the release of the WNT signaling peptide from WNT-secreting cells $[69,70]$. The WNT signaling pathway is a major control pathway for many aspects of embryonic development, including patterning of the central nervous system, and is also involved in axon guidance and synapse formation in adult organisms [71,72]. In addition, defects in WNT signaling are associated with neurological disorders in humans, including schizophrenia and Alzheimer's disease [73]. Selenoprotein P (sepp1a) was also among the most differentially expressed genes with a 1.85-fold upregulation in domesticated zebrafish, similar to previous observations of these strains [43]. The role of SEPP in the brain is not completely understood but the protein plays a vital role in selenium homeostasis [74]. Mouse
SEPP knockout mutants have reduced ability to store selenium in the brain and other tissues, and show severe neurological impairment [75-77]. In humans, selenium levels are associated with disease states including epilepsy, Parkinson's disease, and Alzheimer's disease [74]. Although it is unknown if SEPP plays a role in these disorders, sequence variation in sepp affects the ability to utilize selenium in humans [78].

DAVID identified seven functional categories that were overrepresented among all genes differentially expressed between wild and domesticated zebrafish. After accounting for overlap, the functional groups can be reduced to two categories: vesicle proteins and acyl-CoA binding domain containing proteins. Each of these groups was represented by at most two or three individual genes. The vesicle proteins included synaptophysin $b$ and synaptoporin which are associated with synaptic vesicles and synaptic plasticity $[79,80]$, and SEC31 homolog, a subunit of the coat protein complex II which enables the formation of transport vesicles from the endoplasmic reticulum. Knockout mice lacking synaptophysin are viable but show increased exploratory behavior and reduced learning ability and memory [81], indicating that this gene can be directly involved in behavioral variation. Stress is also known to influence both mRNA and protein levels of synaptophysin in rats but the relationship is complex and influenced by factors including sex and the severity of the stressor [82-84]. Reduced sensitivity to stress has been observed in domesticated fish $[8,85]$ and may be a factor in our study. The acyl-CoA binding domain containing proteins included $a c b d 3$ and acbd4. ACBD3 maintains the structure of the Golgi apparatus, influences protein transport between the Golgi apparatus and the endoplasmic reticulum, and is an important component of several cellular signaling pathways (reviewed by [86]). The function of ACBD4 has not been determined.

\section{Transcriptome variation between zebrafish sexes}

Although not a primary focus of this experiment, we also tested for sex differences in gene expression. We detected only eight sexually dimorphic genes in the brain: insulin-like growth factor 1 (igf1); deiodinase, iodothyronine, type II (dio2); inhibin, beta Aa (inhbaa); endothelial PAS domain protein 1 (epas1); and four unannotated genes (Dr.14275.1.A1_at, Dr.16113.1.S1_at, Dr.16580.1.A1_at, Dr.18139.1.S1_at, Dr.18392.1.A1_at, and Dr.6751.1.S1_at). Of these only dio2 was previously documented as sexually dimorphic in zebrafish brains $[43,87]$. Interestingly, although 40 of the 42 sexually dimorphic genes identified by Santos et al. [87]were represented on the GeneChip ${ }^{\circledR}$ Zebrafish Genome microarray, only eleven were detected as expressed in our study. This lack of concordance with our study is 
surprising, but could result from differences in experimental procedures, microarray platform and chemistry, and statistical analysis. A higher number of sexually dimorphic genes (81 genes) were also detected in brain transcriptomes of immature Atlantic salmon (Salmo salar) [34]. Despite the differences between these studies and ours, all three studies showed substantially fewer sexually dimorphic genes in the brain relative to other tissues, such as liver (1249 genes [88]) and gonads (2940 genes [89]). This result is comparable to observations in mammals [90].

\section{Validation using quantitative real-time PCR}

We performed a technical validation using quantitative real-time PCR (qRT-PCR) to verify expression of six differentially expressed genes identified by the microarray analysis. The genes selected for qRT-PCR validation differed significantly among strains ( gad2, gfap, pomca), between wild and domesticated strains (seppla, synpr), or between the sexes (dio2) in the microarray analysis. The qRT-PCR results were consistent with the microarray analysis for four of the six genes (Figure 2). qRT-PCR measures of gad2 expression did not agree with the microarray results, suggesting that there may be additional factors affecting hybridization to the microarray. Expression of seppla also differed between microarray and qRT-PCR in that the Gaighatta strain had higher levels than expected; however, we previously found agreement between our microarray findings (current study) and qRT-PCR measures of seppla in an independent sample of these strains [43]. This unexpected disagreement may reflect strain-specific regulation of sepp1a expression by dietary selenium levels [43].

\section{Comparison with other studies}

Examination of these findings in a comparative context can allow us to prioritize genes for future analyses. We therefore compared our results to other analyses in zebrafish and other species. Several microarray studies have examined transcriptome variation associated with domestication or fear-related behavioral variation in other vertebrates. These studies include a comparison between wild and domesticated rainbow trout [37], an analysis of the effect of selection for tame behavior in gray fox [35], a comparison between dogs and wolves [36], and an analysis of behavioral variation among inbred mouse lines [47]. Cross-species comparisons of microarray studies are complicated by differences in microarray platforms and chemistry, hybridization efficiencies, experimental design, and statistical analyses. The studies also differed at the scale at which gene expression was measured in the brain. The canid and mouse studies measured expression separately in multiple regions of the brain $[35,36,47]$ while our study and the rainbow trout study
[37] examined gene expression in the entire brain. Regional analyses of gene expression may be able to detect local changes in gene expression that are not detectable in whole brain analyses [91] but brain regions must be selected with care to ensure that relevant regions are included in the analysis.

Despite these complications, we identified sixteen evolutionarily or functionally related groups of genes that were associated with domestication in five vertebrate species, or fear-related behaviors in mice (Table 1). The association of these genes with independently derived domesticated populations of evolutionarily divergent species suggests that these genes may be components of pathways influenced by convergent evolution during domestication, although they may not represent the causative polymorphisms. These genes are involved in a variety of functions including translation initiation, protein folding (DNAj genes), amelioration of oxidative stress (glutathione peroxidases and selenoprotein P), and metabolic function (cytochrome $\mathrm{c}$ oxidases, NADH dehydrogenases). However, a few are known to affect functions in the brain.

A few of these genes are associated with synapse function and long-term potentiation. Syntaxins are components of the SNARE complex which mediates the docking of vesicles with extracellular membranes, including the release of neurotransmitters from axon terminals [92], and appears to be regulated by several syntaxin-binding proteins $[93,94]$. Protein levels of syntaxins increase during long-term potentiation in the rat hippocampus [95]. In studies related to domestication, mRNA expression of syntaxin $1 b 2$ was higher in foxes selected for tameness [35]; expression of syntaxinbinding proteins was higher in domesticated rainbow trout [37] and correlated with fear-related behaviors in mice [47]. In contrast, in our study of zebrafish, expression of three syntaxin genes differed among strains but was not associated with domestication history. Likewise, caspases, such as capase-3, are associated with synaptic plasticity and learning, in addition to their involvement in apoptosis [96,97]. Caspase-3a and capase-8 were upregulated in domesticated populations of zebrafish (current study) and rainbow trout [37]. These observations suggest that synapse development and function may be influenced by domestication.

The association of collagens and hemoglobins with domestication of multiple species was surprising. Collagens are rare in the brain and are usually associated with the meninges surrounding the brain [98]. This includes several of the collagen genes differentially expressed among zebrafish populations (present study), between wild and domesticated rainbow trout [37], and correlated with behavior in mice [47]. It is possible that the meninges may have contaminated the brain samples, although it is not 


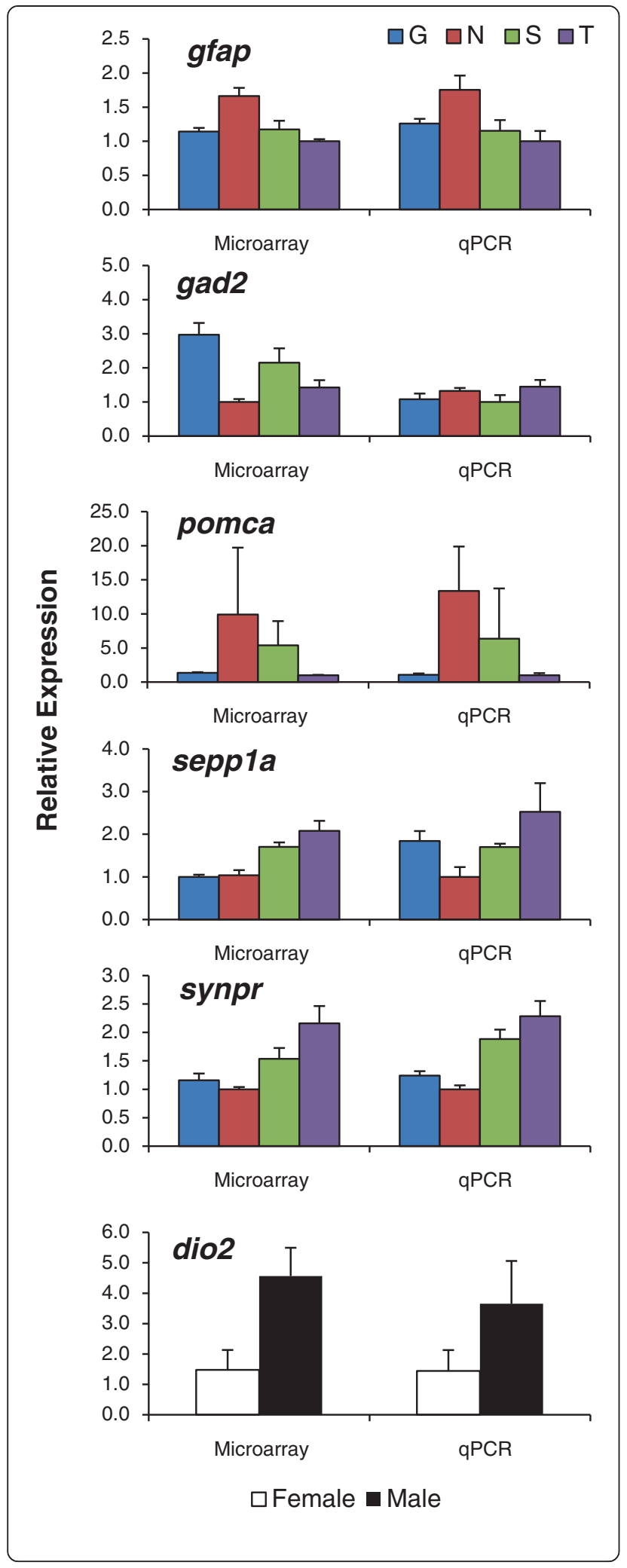

Figure 2 qRT-PCR was used to validate microarray results for six genes. Microarray and qRT-PCR showed similar patterns for five of the six genes: glial fibrillary acidic protein ( $\mathrm{fap}$ ), proopiomelanocortin a (pomca), selenoprotein P1a (sepp 1a), synaptoporin (synpr), and deiodinase, iodothyronine, type II (dio2). Validation failed for glutamate decarboxylase 2 (gad2), suggesting that additional factors may be affecting hybridization to the microarray. Abbreviations: $\mathrm{G}=$ Gaighatta, $\mathrm{N}=$ Nadia, $\mathrm{S}=$ Scientific Hatcheries, $\mathrm{T}=\mathrm{TM} 1$.

clear why this contamination would differ in level between populations in multiple species. Alternatively a few collagen genes are expressed in the brain and appear to be involved in neurological development, including axon guidance and synaptogenesis in the CNS $[98,99]$.

Expression of hemoglobin genes was positively associated with domestication in rainbow trout [37], negatively associated with tameness in foxes [35], and positively associated with open field activity in mice [47]. Hemoglobin genes were also differentially expressed among zebrafish populations. It was recently discovered that hemoglobin genes are expressed in neurons, astrocytes, and oligodendrocytes of rats and humans, and may be involved in oxygen storage and mitochondrial function in the brain $[100,101]$.

Finally, SNP variation has been detected among zebrafish populations and may be associated with the variation in behavior and gene expression we observed here. Whiteley et al. [102] examined SNP variation among thirteen wild populations and three laboratory strains of zebrafish and detected 99 significantly divergent outlier SNP loci that may be signatures of natural selection. Eight of these outlier loci occurred in genes that were also differentially expressed in our analysis among populations (arg2, gpx1a, pho, pspc1, si:dkey-15j16.2, and zgc:77304) and between wild and domesticated populations (bhlhe40 and syntaxin1b), suggesting that variation in the expression of these genes may also be under selection. Their study populations included the laboratory TM1 strain and wild populations in geographic regions from which our wild strains were originally collected.

\section{Conclusion}

Using a high throughput behavior assay, we detected significant variation among zebrafish strains in behaviors related to fearfulness and predator avoidance. This variation showed a strong association with domestication history, consistent with patterns observed in other fish species. While there was substantial inter-strain variation in patterns of gene expression in the brain, far fewer genes were associated with domestication history. This suggests two hypotheses regarding the evolution of behavior during domestication. First, convergent behavioral evolution during domestication may result through 
Table 1 Related genes with brain expression patterns associated with domestication in multiple species

\begin{tabular}{|c|c|c|c|c|c|c|}
\hline Genes & $\begin{array}{l}\text { Zebrafish } \\
\text { Strain }\end{array}$ & $\begin{array}{l}\text { Zebrafish } \\
\text { Domestication }\end{array}$ & $\begin{array}{l}\text { Rainbow Trout } \\
\text { Domestication [37] }\end{array}$ & Fox Tameness [35] & $\begin{array}{l}\text { Dog-Wolf } \\
\text { Comparison [36] }\end{array}$ & $\begin{array}{l}\text { Mouse } \\
\text { Behavior [47] }\end{array}$ \\
\hline Caspase & $\begin{array}{l}\text { casp2, casp3a, } \\
\text { caspb }\end{array}$ & casp3a $(+)$ & casp8 (+) & & & \\
\hline $\begin{array}{l}\text { Coiled-coil domain } \\
\text { containing }\end{array}$ & $\begin{array}{l}\text { ccdc47, ccdc53, } \\
\text { ccdc93, } \\
\text { Dr.18793.1.A1_at }\end{array}$ & Dr.18793.1.A1_at (+) & BU965755 (+) & & & \\
\hline Collagens & $\begin{array}{l}\text { col1a2, col2a1a, } \\
\text { col5a2l, col9a2, } \\
\text { wu:fa99c11, } \\
\text { zgc:56518 }\end{array}$ & & col1a1 $(+)$, col1a2 $(+)$ & & & $\begin{array}{l}\text { col1a } 1^{a} \\
\text { col3a1 }\end{array}$ \\
\hline $\begin{array}{l}\text { Cytochrome } \\
\text { c oxidase }\end{array}$ & & & $\operatorname{cox} 2(-), \operatorname{cox} 3(-)$ & & & $\operatorname{cox} 5 a^{b}$ \\
\hline DNAj & dnajc12 & dnajc3 (-) & & & & $\begin{array}{l}\text { dnajc6 } \\
(\text { Al840916) }\end{array}$ \\
\hline $\begin{array}{l}\text { Eukaryotic translation } \\
\text { initiation factors }\end{array}$ & eif1ax, eif4enif1 & $\begin{array}{l}\text { eif1ax (+), } \\
\text { eif4enif1 }(-)\end{array}$ & eif3s2 (+), eif3s7 (+) & & & \\
\hline Glutathione peroxidases & gpx1a, gpx4a & & gpx3 (-) & & & $g p \times 3^{d}$ \\
\hline Hemoglobins & hbaa1, ba1 & & $\begin{array}{l}\text { hba,hba1, hba4, hbb, } \\
\text { hbb1, hbb2, hbb4 } \\
(\text { all +) }\end{array}$ & $\begin{array}{l}\text { hbe, hbg1, hbg2, } \\
\text { hba, hbz (all -) }\end{array}$ & & hbaal ${ }^{\mathrm{e}}$ \\
\hline $\begin{array}{l}\text { NADH dehydrogenase } \\
\text { (ubiquinone) }\end{array}$ & & & ndf1a4 (+) & ndufb8 (-) & & \\
\hline $\begin{array}{l}\text { Neurofilament, light } \\
\text { peptide }\end{array}$ & & & CB514125 (+) & & & nefl ${ }^{\mathrm{e}}$ \\
\hline $\begin{array}{l}\text { Potassium channel } \\
\text { proteins }\end{array}$ & $\begin{array}{l}\text { Dr.16785.1.A1_at } \\
\text { (kcnk1) }\end{array}$ & & & & kcnj4 (-) & $\begin{array}{l}\text { Al835316 } \\
(\text { kcnc2 })^{\mathrm{a}}\end{array}$ \\
\hline $\begin{array}{l}\text { Purkinje cell } \\
\text { protein } 4\end{array}$ & & & & $\operatorname{pcp} 4\left(^{*}\right)$ & pcp4 (+) & \\
\hline Selenoprotein P & sepp1a & sepp1a (+) & & & sepp1 (+) & \\
\hline Syntaxins & $\begin{array}{l}\text { stx3a, stx6, } \\
\text { syntaxin } 1 b\end{array}$ & & & $\mathrm{stx} 1 \mathrm{~b} 2(+)$ & & \\
\hline $\begin{array}{l}\text { Syntaxin binding } \\
\text { proteins }\end{array}$ & & & stxbp3 $(+)$ & & & $\begin{array}{l}\text { stxbp2 } 2^{b} \\
\text { stxbp6 }\end{array}$ \\
\hline $\begin{array}{l}\text { Transthyretin } \\
\text { (prealbumin, } \\
\text { amyloidosis type I) }\end{array}$ & & & & $\operatorname{ttr}\left({ }^{*}\right)$ & $\operatorname{ttr}(+)$ & \\
\hline
\end{tabular}

Studies included the present study on zebrafish (Danio rerio), an analysis of domestication in rainbow trout (Oncorhynchus mykiss) [37], silver fox (Vulpes vulpes) selected for tameness [35], a comparison between dog (Canis familiaris) and wolf (Canius lupus) [36], and an analysis of strain variation in laboratory mice (Mus musculus) [47]. Positive signs (+) indicated up-regulation in domesticated populations relative to wild, while negative signs (-) indicate down-regulation. An asterisk $\left(^{*}\right)$ indicates that the direction of differential expression differed among brain regions.

${ }^{a}$ Negative correlation with open field activity; ${ }^{b}$ Positive correlation with distance traveled after ethanol administration; ${ }^{c}$ Positive correlation with electroconvulsive threshold; ${ }^{d}$ Negative correlation with electroconvulsive threshold; ${ }^{\text {e }}$ Positive correlation with open field activity.

independent alterations in different pathways that achieve similar phenotypic effects. If this is the case, each of our domesticated zebrafish populations would have different genes associated with behavioral variation, and these genes would be lost among the large number of genes varying among populations and therefore undetectable in our comparison. Alternatively, evolution of these behavioral phenotypes may involve only a few genes or pathways to achieve the behavioral variations observed here. In our study, the number of genes associated with domestication in zebrafish is comparable to that associated with within-population behavioral variation in other fish species, such as differences between dominant and subordinate cichlids (Astatotilapia burtoni, 171 genes, [103]) and between sneaker and migratory males in Atlantic salmon (Salmo salar, 432 genes, [34]). This suggests that behavioral variation can be associated with alterations in the expression of relatively few genes in the brain. In addition, identification of genes associated with domestication in multiple vertebrate species may indicate convergent evolution of a few key molecular pathways during domestication. Full evaluation of these hypotheses is beyond the scope of our study and would require more comprehensive analyses using both multiple populations and multiple species. However transcriptome variation among 
populations can be substantial and should be given careful consideration when designing genomic analyses of behavior and other traits.

\section{Methods \\ Zebrafish strains}

We used zebrafish from four distinct strains for our experiments. Two of these strains have been reared in captivity for more than thirty generations each $[9,43,44]$. The Scientific Hatcheries strain (SH) was originally obtained from a commercial breeder (Scientific Hatcheries, Huntington, CA) and reared in our laboratory for three generations prior to the experiment. It is difficult to determine the total number of generations for which this strain has been in captivity, but it is known to be at least thirty. The TM1 strain was founded from a pet store population and reared for 24 generations at the University of Miami [66] and a further six generations prior to the experiment at the University of Idaho. The TM1 strain is GFP transgenic using a $\beta$-actin promoter [66]. Two additional strains, Nadia and Gaighata, were recently derived from wild populations in India. The Nadia strain was originally collected in India in 1999. At the time of this study, the strain had been reared in the laboratory for six generations, remaining qualitatively similar to the original wild collections $[9,43,44]$. The Gaighatta strain was collected in India in 2005, and was in its first generation of lab rearing at the time of this study.

Prior to the experiment, all zebrafish were reared in a recirculating zebrafish facility at the University of Idaho, designed by Aquaneering Inc. (San Diego, CA). Fish were feed twice daily with a combination of commercial flake food and Artemia nauplii. Temperature of the facility was maintained at $28{ }^{\circ} \mathrm{C}$ with a constant $14 \mathrm{~h}$ light: $10 \mathrm{~h}$ dark cycle. These rearing conditions were maintained during the behavior assays. All procedures involving animals were approved by the University of Idaho Animal Care and Use Committee.

\section{Behavior assays}

Sixteen adult fish (4 to 6 months old) from each strain were randomly assigned to $1-\mathrm{L}$ aquaria $(22 \mathrm{~cm}$ long, $15 \mathrm{~cm}$ high, $5 \mathrm{~cm}$ wide), one fish per aquarium. The aquaria were delimited into six 2 -cm vertical zones using thin twine tied across the front of the entire row of aquaria. Fish were visually isolated by placing paper barriers between aquaria. Each aquarium was labeled with a unique numerical identifier so that information regarding strain and sex was unknown to the observer. The fish were then allowed to acclimatize overnight. Starting the next day, behaviors were scored by a single observer, unaware of the strain identity of each fish, three times per day for 10 days (30 observation periods per individual fish). Observations of behavior were conducted at 0830 hours (one hour prior to the morning feeding), 1230 hours, and 1630 hours (one hour after the afternoon feeding) following methods developed in our laboratory $[43,46]$. Briefly, each fish was observed at the eye level of the observer from a distance of $0.5 \mathrm{~m}$ for a period of three seconds, and its vertical and horizontal location was recorded three times at one second intervals. Vertical location was coded as an integer representing the vertical zone occupied by the fish $(1=$ top, $6=$ bottom); the final "Vertical Depth" score for each individual was computed as the mean across all 30 observation periods. The horizontal location of the fish was recorded as a binary variable, with 1 indicating the fish was within one body length of the front of the tank and 0 indicating the fish was not. "Horizontal Position" was calculated as mean horizontal location across all 30 observations and is an estimate of the proportion of time the animal spent within one body length of the front of the tank, nearest the human observer, over the course of the experiment. All behavior experiments were performed in a common rearing environment experimental design in which extreme care was taken to expose all fish to identical rearing conditions. These behaviors have been shown to have repeatabilities between 0.4 and 0.6 [46].

Sex of each fish was determined by inspection of external sex characteristics. Our goal was to test equal numbers of males and females from each strain; however, the final experiment was slightly imbalanced due to unequal sex ratios in the Nadia (male-biased) and $\mathrm{SH}$ (female-biased) strains. This did not affect our behavioral analyses, as we detected no differences in behavior between the sexes (data not shown).

All behavior data were analyzed using SAS, version 9.1 (SAS Institute, Cary, NC). We tested the effect of strain on behavior phenotypes using one-way Analysis of Variance (ANOVA) with the GLM procedure. The model included Sex, Domestication history, and Strain nested within Domestication history as fixed effects in the model. The residuals were visually examined to ensure that the assumption of normality was not violated.

\section{Tissue isolation and RNA extraction}

After behavior assays were completed, fish were removed from the individual tanks and placed in one of sixteen 3-L group tanks. Four fish of the same sex and strain were assigned to each tank, resulting in four replicate tanks per strain. In the case of strains with biased sex ratios (see above), some tanks contained either 3 or 5 fish. The fish remained in these tanks during the period between collection of behavioral data and isolation of tissues for microarray analysis (one week).

On the sampling day, each fish was anesthetized in $170 \mathrm{mg} \mathrm{L}^{-1}$ tricaine methanesulfonate (MS222, Western 
Chemical Inc., Ferndale, WA), briefly blotted on a paper towel, and rapidly measured for standard length and body mass. The brain was then quickly removed and homogenized in TRIzol (Invitrogen, Carlsbad, CA). Brains from all individuals in a tank were homogenized together, for a total of two biological replicate pools per sex per strain (16 microarrays total). Total RNA was then extracted using the TRIzol method following manufacturer's protocol. RNA quality was confirmed using gel electrophoresis and visual spectrophotometry using a Nanodrop spectrophotometer. All samples had 260/ $280 \mathrm{~nm}$ absorbance ratios between 1.85 and 2.05, and 260/230 $\mathrm{nm}$ absorbance ratios greater than 0.85 .

\section{Microarray hybridization}

For each array, $10 \mu \mathrm{g}$ of total RNA were converted to cDNA. Biotinylated cRNA was then produced in vitro using the GeneChip expression 3' amplification onecycle target labeling kit (Affymetrix, Santa Clara, CA, USA). Affymetrix Zebrafish Genome Arrays ( 14,900 transcripts) were hybridized with fragmented biotinylated cRNA for $16 \mathrm{~h}$ at $45{ }^{\circ} \mathrm{C}$ with constant rotation (45 rpm), and processed using the Affymetrix GeneChip Fluidic Station 450. Streptavidin-conjugated phycoerythrin (SAPE) was used for staining, followed by amplification using a biotinylated anti-streptavidin antibody. This was followed by another round of SAPE prior to scanning using a GeneChip Scanner 3000 (Affymetrix). All microarray procedures were performed at the Genomics Core Facility of the Center for Reproductive Biology at Washington State University (Pullman, WA).

\section{Statistical analysis of microarray data}

CEL files containing raw data were then processed and analyzed using $\mathrm{R}$ software and Bioconductor packages $[104,105]$. These CEL files have been deposited with the NCBI Gene Expression Omnibus (GEO, Accession: GSE38729, http://www.ncbi.nlm.nih.gov/geo). Microarray hybridization data were examined for physical anomalies on the chip by pseudochip and residual error visualizations. Quality assurance of microarray data was completed using the affyQAReport function from the Bioconductor package affyQCReport. Hybridization and housekeeping controls, RNA degradation, sample clustering, NUSE plots, LPE plots, and RLE plots all showed high quality data (not shown) and no chips were removed. The arrays were then pre-processed using the Robust Multi-array Average (RMA) procedure [106-108] using the affy package [109]. Next, unexpressed and low variability genes were removed by unbiased filtering. Affymetrix present-marginal-absent (PMA) calls were determined using a $P$-value cut off for absent of greater than 0.04 and present less than 0.04; marginal calls were treated as absent. Unexpressed genes were then defined as having a signal less than the expression value at which $99 \%$ of genes were called as absent across all samples. A filter on interquartile range was also applied to remove genes with low variability. Genes with an interquartile range of less than 0.5 across all chips in the experiment were excluded, reducing the dataset further to 7,958 genes.

Signal intensities were also examined at the probe level to identify single feature polymorphisms (SFPs), differences at the probe level due to genetic polymorphisms rather than expression differences, which may also impact computed expression values. Briefly, in R using previously described methods [61], the RMA normalized expression estimate for each probe set was subtracted from background corrected and normalized expression levels at individual probes within the probe set. Normalized residuals were analyzed using significance analysis of microarrays (SAM) [110] within the siggenes package to detect features with a significant effect for strain (FDR adjusted $\alpha<0.01$ ). A total of 3,199 genes with significant SFPs were then removed from the analysis.

The Linear Models for Microarray Data (limma) package was then used to perform differential expression analysis on the filtered gene list using a linear model on $\log _{2}$ signal values with an empirical Bayes correction to the variance $[64,65]$. Comparisons of interest were extracted through contrasts, and $P$-values were corrected for multiple comparisons using the Benjamini and Hochberg method (FDR = 5 \%) [111]. The data were initially analyzed with a fully crossed factorial model of Strain and Sex. However, because the Sex and interaction terms were not significant for the vast majority of genes (see Results), we also tested for differential expression among strains using a model that excluded sex. The effect of domestication history was tested using contrasts between wild and domesticated strains.

Functional analyses of the resulting gene lists were performed using DAVID version 6.7 [67,68]. Functional categories were evaluated against the probability that they appeared in lists of differentially expressed genes at random based on their representation in the full list of genes that were classified as expressed in the zebrafish brain in our analysis. Functional classifications considered in the analysis included gene ontologies (GOs, [112]), COG ontologies, protein domains from PIR superfamilies, Interpro, and SMART databases, KEGG pathways, SP PIR keywords, and Up Seq features. Analysis of gene ontologies used the "FAT" option which filters the output, removing upper level GOs primarily from the top five levels of the hierarchy, in favor of more specific GOs that are often more informative. Categories were considered overrepresented if the EASE score was less than 0.05 . We also report P-values adjusted for multiple tests using the Benjamini-Hochberg correction 
[111]. The Functional Annotation Clustering tool was used to identify categories with overlapping lists of differentially expressed genes.

\section{qRT-PCR validation}

Technical validation of microarray results was performed using qRT-PCR on the sixteen sample pools used in the microarray analysis. Six genes were selected in order to represent multiple patterns of expression, including genes that differed among strains, between wild and domesticated strains, or between the sexes. The primer sequences for these genes are provided in Additional file 4. For each sample, $400 \mathrm{ng}$ total RNA were converted to cDNA in a $20 \mu \mathrm{l}$ total volume containing $100 \mathrm{ng}$ random primers (Invitrogen, Carlsbad, CA), $0.5 \mathrm{mM}$ dNTP, $0.05 \mathrm{M}$ DTT, 1X SuperScript reaction buffer, and SuperScript II reverse transcriptase (100 U; Invitrogen). The resulting cDNA was diluted 1:5 with TE $(\mathrm{pH} 8)$ and used as template for qRT-PCR using $\mathrm{SYBR}^{\circledR}$ Green PCR Master Mix (Applied Biosystems, Foster City, CA) on an ABI 7900HT Fast Real-Time PCR System, following the manufacturer's protocol. Specificity of the qRT-PCR was verified through melting curve analysis. $\beta$ actin was used as a reference gene because expression of this gene did not differ among strains in the microarray analysis. Standard curves and negative controls were included for both target and reference genes on every plate. Standard curves consisted of a 1:4 dilution series of a cDNA pool created from all 16 samples.

qRT-PCR data were analyzed using mixed model analysis of covariance (ANCOVA) using the $l m$ function in $\mathrm{R}$. This approach analyzed expression of the target gene $\left(\mathrm{C}_{\mathrm{T}} \mathrm{s}\right)$ while simultaneously normalizing expression by including expression of the reference gene $\left(C_{T} \mathrm{~s}\right)$ as a covariate in the model $[88,113]$. We employed a fully crossed factorial model using the main effects of Strain and Sex. When the effect of Strain was significant, pairwise comparisons were performed using Tukey's Studentized Range test.

\section{Additional files}

Additional file 1: Microarray analysis revealed 1,752 probe sets that differed significantly in expression among strains of zebrafish (Danio rerio).

Additional file 2: Functional categories overrepresented among genes differentially expressed among strains of zebrafish (Danio rerio), revealed by DAVID analysis.

Additional file 3: Microarray analysis revealed 112 probe sets that differed significantly between domesticated and wild zebrafish strains.

Additional file 4: Genes and primers for validation of microarray results with quantitative Real-Time PCR (qRT-PCR).

\section{Competing interests}

The authors have no competing interests.

\section{Authors' contributions}

BDR conceived and designed the experiment. BDR and RED drafted the manuscript. EJC reared fish and collected behavior data. EJC and RED prepared RNA samples for microarray analysis. RED, EJC, SB, and SMW performed the GRT-PCR validations. MLS, BDR and RED performed statistical analyses. All authors read and approved the final manuscript.

\section{Acknowledgements}

The authors thank Mary Oswald, Kevin Kelliher, Scott Nuismer, and Deborah Stenkamp for discussion and comments on previous versions of the manuscript, and Derek Pouchnik for his help with microarray analyses. We also thank Patt Gibbs for originally providing us with a breeding stock of the TM1 strain, and Deepak Nopany and John Godwin for collection of the Gaighatta strain. This work was supported by the NSF-Idaho EPSCoR Program and by the National Science Foundation under award numbers EPS-0132626 and EPS-0447689 (BDR) and IOS-0818904 (BDR and RED). Participation by SW was supported by the National Science Foundation REU grant (EEC-0648202) awarded to R. Wells (University of Idaho). The University of Idaho zebrafish facility was constructed with funding from the National Institutes of Health Grant \# P20 RR016448 from the COBRE Program of the National Center for Research Resources.

\section{Author details}

${ }^{1}$ Department of Biological Sciences and Program in Bioinformatics and Computational Biology, University of Idaho, Moscow, ID 83844, USA.

${ }^{2}$ Department of Biology and Program in Biomedical Engineering and Biotechnology, University of Massachusetts-Dartmouth, North Dartmouth, MA 02747, USA. ${ }^{3}$ Department of Computer Science and Program in Bioinformatics and Computational Biology, University of Idaho, Moscow, ID 83844, USA.

Received: 9 February 2012 Accepted: 28 June 2012

Published: 20 July 2012

\section{References}

1. Price EO: Behavioral genetics and the process of animal domestication. In Genetics and the behavior of domestic animals. Edited by Grandin T. Academic Press: San Diego; 1998:41-65.

2. Price EO: Behavioral development in animals undergoing domestication. Applied Animal Behaviour Science 1999, 65(3):245-271.

3. Waples RS: Dispelling some myths about hatcheries. Fisheries 1999, 24(2):12-21

4. Devlin RH, Biagi CA, Yesaki TY, Smailus DE, Byatt JC: Growth of domesticated transgenic fish. Nature 2001, 409(6822):781-782.

5. Fleming IA, Agustsson T, Finstad B, Johnsson Jl, Björnsson BT: Effects of domestication on growth physiology and endocrinology of Atlantic salmon (Salmo salar). Can J Fish Aquat Sci 2002, 59(8):1323-1330.

6. Johnsson Jl, Petersson E, Jönsson E, Björnsson BT, Järvi T: Domestication and growth hormone alter antipredator behaviour and growth patterns in juvenile brown trout, Salmo trutta. Can J Fish Aquat Sci 1996, 53(7): 1546-1554.

7. Künzl C, Sachser N: The behavioral endocrinology of domestication: a comparison between the domestic guinea pig (Cavia aperea f. porcellus) and its wild ancestor, the cavy (Cavia aperea). Horm Behav 1999, 35(1):28-37

8. Woodward CC, Strange RJ: Physiological stress responses in wild and hatchery-reared rainbow trout. Trans Am Fish Soc 1987, 116(4):574-579.

9. Oswald M, Robison BD: Strain-specific alteration of zebrafish feeding behavior in response to aversive stimuli. Can J Zool 2008, 86(10):1085-1094.

10. Berejikian BA, Mathews SB, Quinn TP: Effects of hatchery and wild ancestry and rearing environments on the development of agonistic behavior in steelhead trout (Oncorhynchus mykiss) fry. Can J Fish Aquat Sci 1996, 53(9):2004-2014.

11. Johnsson Jl, Abrahams MV: Interbreeding with domestic strain increases foraging under threat of predation in juvenile steelhead trout (Oncorhynchus mykiss): an experimental study. Can J Fish Aquat Sci 1991, 48:243-247.

12. Harri M, Mononen J, Ahola L, Plyusnina I, Rekila T: Behavioural and physiological differences between silver foxes selected and not selected for domestic behaviour. Animal Welfare 2003, 12(3):305-314. 
13. Huntingford FA: Implications of domestication and rearing conditions for the behaviour of cultivated fishes. J Fish Biol 2004, 65A(S1):122-142.

14. Jensen $P$, Andersson L: Genomics meets ethology: A new route to understanding domestication, behavior, and sustainability in animal breeding. Ambio 2005, 34(4-5):320-324

15. Britten RJ, Davidson EH: Gene regulation for higher cells: a theory. Science 1969, 165(3891):349-357.

16. Fay JC, Wittkopp PJ: Evaluating the role of natural selection in the evolution of gene regulation. Heredity 2008, 100(2):191-199.

17. Whitehead A, Crawford DL: Variation within and among species in gene expression: raw material for evolution. Mol Ecol 2006, 15(5):1197-1211.

18. Fay JC, McCullough HL, Sniegowski PD, Eisen MB: Population genetic variation in gene expression is associated with phenotypic variation in Saccharomyces cerevisiae. Genome Biol 2004, 5(4):R26.

19. Hutter S, Saminadin-Peter SS, Stephan W, Parsch J: Gene expression variation in African and European populations of Drosophila melanogaster. Genome Biol 2008, 9(1):R12.

20. Giger T, Excoffier L, Amstutz U, Day PJR, Champigneulle A, Hansen MM, Kelso J, Largiadèr CR: Population transcriptomics of life-history variation in the genus Salmo. Mol Ecol 2008, 17(13):3095-3108.

21. Oleksiak MF, Churchill GA, Crawford DL: Variation in gene expression within and among natural populations. Nat Genet 2002, 32(2):261-266.

22. Roberge C, Einum S, Guderley H, Bernatchez L: Rapid parallel evolutionary changes of gene transcription profiles in farmed Atlantic salmon. Mol Ecol 2006, 15(1):9-20.

23. Townsend JP, Cavalieri D, Hartl DL: Population genetic variation in genome-wide gene expression. Mol Biol Evol 2003, 20(6):955-963.

24. Whitehead A, Crawford DL: Variation in tissue-specific gene expression among natural populations. Genome Biol 2005, 6(2):R13.

25. Spielman RS, Bastone LA, Burdick JT, Morley M, Ewens WJ, Cheung VG: Common genetic variants account for differences in gene expression among ethnic groups. Nat Genet 2007, 39(2):226-231.

26. Storey JD, Madeoy J, Strout JL, Wurfel M, Ronald J, Akey JM: Geneexpression variation within and among human populations. Am J Hum Genet 2007, 80(3):502-509.

27. Brem RB, Kruglyak $L$ : The landscape of genetic complexity across 5,700 gene expression traits in yeast. Proc Natl Acad Sci USA 2005, 102(5):1572-1577.

28. Morley M, Molony CM, Weber TM, Devlin JL, Ewens KG, Spielman RS, Cheung VG: Genetic analysis of genome-wide variation in human gene expression. Nature 2004, 430(7001):743-747.

29. Roberge C, Guderley H, Bernatchez L: Genomewide identification of genes under directional selection: gene transcription QST scan in diverging Atlantic salmon subpopulations. Genetics 2007, 177:1011-1022.

30. Whiteley AR, Derome N, Rogers SM, St-Cyr J, Laroche J, Labbe A, Nolte A, Renaut $S$, Jeukens J, Bernatchez L: The phenomics and expression quantitative trait locus mapping of brain transcriptomes regulating adaptive divergence in lake whitefish species pairs (Coregonus sp.) Genetics 2008, 180(1):147-164.

31. Landry CR, Townsend JP, Hartl DL, Cavalieri D: Ecological and evolutionary genomics of Saccharomyces cerevisiae. Mol Ecol 2006, 15(3):575-591.

32. Larsen PF, Nielsen EE, Williams TD, Hemmer-Hansen J, Chipman JK, Kruhøffer M, Grønkjær P, George SG, Dyrskjøt L, Loeschcke V: Adaptive differences in gene expression in European flounder (Platichthys flesus). Mol Ecol 2007, 16(22):4674-4683.

33. Whitehead A, Crawford DL: Neutral and adaptive variation in gene expression. Proc Natl Acad Sci USA 2006, 103(14):5425-5430.

34. Aubin-Horth $\mathrm{N}$, Landry $\mathrm{CR}$, Letcher $\mathrm{BH}$, Hofmann HA: Alternative life histories shape brain gene expression profiles in males of the same population. Proceedings of the Royal Society of London, Series B 2005, 272(1573):1655-1662.

35. Lindberg J, Bjornerfeldt S, Saetre P, Svartberg K, Seehuus B, Bakken M, Vila C, Jazin E: Selection for tameness has changed brain gene expression in silver foxes. Curr Biol 2005, 15(22):R915-R916.

36. Saetre $P$, Lindberg J, Leonard JA, Olsson $K$, Pettersson U, Ellegren $H_{\text {, }}$ Bergström TF, Vilà C, Jazin E: From wild wolf to domestic dog: gene expression changes in the brain. Mol Brain Res 2004, 126(2):198-206.

37. Tymchuk W, Sakhrani D, Devlin R: Domestication causes large-scale effects on gene expression in rainbow trout: analysis of muscle, liver and brain transcriptomes. Gen Comp Endocrinol 2009, 164(2-3):175-183.
38. Gerlai R: Zebrafish: an uncharted behavior genetic model. Behav Genet 2003, 33(5):461-468.

39. Guo S: Linking genes to brain, behavior and neurological diseases: what can we learn from zebrafish? Genes Brain Behav 2004, 3(2):63-74.

40. Sison M, Cawker J, Buske C, Gerlai R: Fishing for genes influencing vertebrate behavior: zebrafish making headway. Lab Anim 2006, 35(5):33-39.

41. Tropepe V, Sive HL: Can zebrafish be used as a model to study the neurodevelopmental causes of autism? Genes Brain Behav 2003, 2(5):268-281.

42. Wright D, Rimmer LB, Pritchard VL, Krause J, Butlin RK: Inter and intrapopulation variation in shoaling and boldness in the zebrafish (Danio rerio). Naturwissenschaften 2003, 90(8):374-377.

43. Benner MJ, Drew RE, Hardy RW, Robison BD: Zebrafish (Danio rerio) vary by strain and sex in their behavioral and transcriptional responses to selenium supplementation. Comp Biochem Physiol A Mol Integr Physiol 2010, 157(4):310-318.

44. Robison BD, Rowland W: A potential model system for studying the genetics of domestication: behavioral variation among wild and domesticated strains of zebra danio (Danio rerio). Can J Fish Aquat Sci 2005, 62(9):2046-2054.

45. Wright D, Nakamichi R, Krause J, Butlin RK: QTL analysis of behavioral and morphological differentiation between wild and laboratory zebrafish (Danio rerio). Behav Genet 2006, 36(2):271-284.

46. Robison BD, Singer M, Benner MJ, Oswald ME: A high throughput and inexpensive assay for anxiety related behaviors in the zebrafish, based on place preference and latency to feed. In Zebrafish Protocols for Neurobehavioral Research. Edited by Kalueff AV, Stewart AM. New York, New York: Humana Press; in press.

47. Letwin NE, Kafkafi N, Benjamini Y, Mayo C, Frank BC, Luu T, Lee NH, Elmer $\mathrm{Gl}$ : Combined application of behavior genetics and microarray analysis to identify regional expression themes and gene-behavior associations. J Neurosci 2006, 26(20):5277-5287.

48. Reinhardt UG: Selection for surface feeding in farmed and sea-ranched masu salmon juveniles. Trans Am Fish Soc 2001, 130(1):155-158.

49. Weber ED, Fausch KD: Interactions between hatchery and wild salmonids in streams: differences in biology and evidence for competition. Can J Fish Aquat Sci 2003, 60(8):1018-1036.

50. Hamilton IM, Dill LM: Monopolization of food by zebrafish increases in risky habitats. Can J Zool 2002, 80(12):2164-2169.

51. Rehnberg BG, Smith JF: The influence of alarm substance and shoal size on the behavior of zebra danios. J Fish Biol 1988, 33(1):155-163.

52. Iguchi K, Matsubara N, Hakoyama H: Behavioural individuality assessed from two strains of cloned fish. Anim Behav 2001, 61(2):351-356.

53. Sundström LF, Devlin RH, Johnsson Jl, Biagi CA: Vertical position reflects increased feeding motivation in growth hormone transgenic coho salmon (Oncorhynchus kisutch). Ethology 2003, 109(8):701-712.

54. Egan RJ, Bergner CL, Hart PC, Cachat JM, Canavello PR, Elegante MF, Elkhayat SI, Bartels BK, Tien AK, Tien DH, et al: Understanding behavioral and physiological phenotypes of stress and anxiety in zebrafish. Behav Brain Res 2009, 205(1):38-44.

55. Bachman RA: Foraging behaviour of free-ranging wild and hatchery brown trout in a stream. Trans Am Fish Soc 1984, 113(1):1-31.

56. Lucas MD, Drew RE, Wheeler PA, Verrell PA, Thorgaard GH: Behavioral differences among rainbow trout clonal lines. Behav Genet 2004 34(3):355-365.

57. Moyle PB: Comparative behavior of young brook trout of domestic and wild origin. Progressive Fish-Culturist 1969, 31(1):51-59.

58. Vincent RE: Some influences of domestication upon three stocks of brook trout (Salvelinus fontinalis Mitchill). Trans Am Fish Soc 1960, 89(1):35-52

59. Yamamoto T, Reinhardt UG: Dominance and predator avoidance in domesticated and wild masu salmon Oncorhynchus masou. Fisheries Science 2003, 69(1):88-94

60. Biro PA, Abrahams MV, Post JR, Parkinson EA: Behavioural trade-offs between growth and mortality explain evolution of submaximal growth rates. J Anim Ecol 2006, 75(5):1165-1171.

61. Coram TE, Settles ML, Wang M, Chen X: Surveying expression level polymorphism and single-feature polymorphism in near-isogenic wheat lines differing for the Yr5 stripe rust resistance locus. Theor Appl Genet 2008, 117(3):401-411. 
62. Gilad Y, Rifkin SA, Bertone P, Gerstein M, White KP: Multi-species microarrays reveal the effect of sequence divergence on gene expression profiles. Genome Res 2005, 15(5):674-680

63. Xu WW, Cho S, Yang SS, Bolon Y-T, Bilgic H, Jia H, Xiong Y, Muehlbauer GJ: Single-feature polymorphism discovery by computing probe affinity shape powers. BMC Genomics 2009, 10:48.

64. Smyth GK: Linear models and empirical Bayes methods for assessing differential expression in microarray experiments. Stat Appl Genet Mol Biol 2004, 3(1):3

65. Smyth GK: Limma: linear models for microarray data. In Bioinformatics and Computational Biology Solutions using $R$ and Bioconductor. Edited by Gentleman R, Carey V, Dudoit S, Irizarry R, Huber W. New York: Springer; 2005:397-420.

66. Gibbs PDL, Schmale MC: GFP as a genetic marker scorable throughout the life cycle of transgenic zebra fish. Marine Biotechnol 2000, 2(2): $107-125$.

67. Dennis G, Sherman BT, Hosack DA, Yang J, Gao W, Lane HC, Lempicki RA: DAVID: Database for Annotation, Visualization, and Integrated Discovery. Genome Biol 2003, 4(9):R60.

68. Huang DW, Sherman BT, Lempicki RA: Systematic and integrative analysis of large gene lists using DAVID Bioinformatics Resources. Nat Protoc 2009, 4(1):44-57.

69. Bänziger C, Soldini D, Schütt C, Zipperlen P, Hausmann G, Basler K: Wntless, a conserved membrane protein dedicated to the secretion of Wnt proteins from signaling cells. Cell 2006, 125(3):509-522.

70. Bartscherer K, Pelte N, Ingelfinger D, Boutros M: Secretion of Wnt ligands requires Evi, a conserved transmembrane protein. Cell 2006, 125(3): 523-533.

71. Korkut C, Ataman B, Ramachandran P, Ashley J, Barria R, Gherbesi N, Budnik $\mathrm{V}$ : Trans-synaptic transmission of vesicular Wnt signals through Evi/ Wntless. Cell 2009, 139(2):393-404.

72. Salinas PC, Zou Y: Wnt signaling in neural circuit assembly. Annu Rev Neurosci 2008, 31:339-358.

73. De Ferrari GV, Moon RT: The ups and downs of Wnt signaling in prevalent neurological disorders. Oncogene 2006, 57(7545):7545-7553.

74. Schweizer U, Schomburg L, Savaskan NE: The neurobiology of selenium: lessons from transgenic mice. J Nutr 2004, 134(4):707-710.

75. Hill KE, Zhou J, McMahan WJ, Motley AK, Atkins JF, Gesteland RF, Burk RF: Deletion of selenoprotein $\mathrm{P}$ alters distribution of selenium in the mouse. J Biol Chem 2003, 278(16):13640-13646.

76. Hill KE, Zhou J, McMahan WJ, Motley AK, Burk RF: Neurological dysfunction occurs in mice with targeted deletion of the selenoprotein $\mathrm{P}$ gene. J Nutr 2004, 134(1):157-161

77. Schomburg L, Schweizer U, Holtmann B, Flohé L, Sendtner M, Köhrle J: Gene disruption discloses role of selenoprotein $\mathrm{P}$ in selenium delivery to target tissues. Biochem J 2003, 370(Pt. 2):397-402.

78. Méplan C, Crosley LK, Nicol F, Beckett GJ, Howie AF, Hill KE, Horgan G, Mathers JC, Arthur JR, Hesketh JE: Genetic polymorphisms in the human selenoprotein $\mathrm{P}$ gene determine the response of selenoprotein markers to selenium supplementation in a gender-specific manner (the SELGEN study). FASEB J 2007, 21(12):3063-3074.

79. Janz R, Sudhof TC, Hammer RE, Unni V, Siegelbaum SA, Bolshakov VY: Essential roles in synaptic plasticity for synaptogyrin I and synaptophysin I. Neuron 1999, 24:687-700.

80. Janz R, Sudhof TC: Cellugyrin, a novel ubiquitous form of synaptogyrin that is phosphorylated by pp 60c-src. J Biol Chem 1998, 273(5):2851-2857.

81. Schmitt U, Tanimoto N, Seeliger M, Schaeffel F, Leube RE: Detection of behavioral alterations and learning deficits in mice lacking synaptophysin. Neuroscience 2009, 162:234-243.

82. Thome J, Pesold B, Baader M, Hu M, Gewirtz JC, Duman RS, Henn FA: Stress differentially regulates synaptophysin and synaptotagmin expression in hippocampus. Biol Psychiatry 2001, 50:809-812.

83. Gao Y, Bezchlibnyk YB, Sun X, Wang J-F, McEwen BS, Young LT: Effects of restraint stress on the expression of proteins involved in synaptic vesicle exocytosis in the hippocampus. Neuroscience 2006, 141:1139-1148.

84. Carvalho-Netto EF, Myers B, Jones K, Solomon MB, Herman JP: Sex differences in synaptic plasticity in stress-responsive brain regions following chronic variable stress. Physiol Behav 2011, 104:242-247.

85. Salonius K, Iwama GK: Effects of early rearing environment on stress response, immune function, and disease resistance in juvenile coho
(Oncorhynchus kisutch) and chinook salmon (O. tshawytscha). Can J Fish Aquat Sci 1993, 50:759-766.

86. Fan J, Liu J, Culty M, Papadopoulos V: Acyl-coenzyme A binding domain containing 3 (ACBD3; PAP7; GCP60): An emerging signaling molecule. Prog Lipid Res 2010, 49:218-234.

87. Santos EM, Kille P, Workman VL, Paull GC, Tyler CR: Sexually dimorphic gene expression in the brains of mature zebrafish. Comp Biochem Physiol A Mol Integr Physiol 2008, 149(3):314-324.

88. Robison BD, Drew RE, Murdoch GK, Powell M, Rodnick KJ, Settles M, Stone D, Churchill E, Hill RA, Papasani MR, et al: Sexual dimorphism in hepatic gene expression and the response to dietary carbohydrate manipulation in the zebrafish (Danio rerio). Comp Biochem Physiol Part D Genomics Proteomics 2008, 3(2):141-154.

89. Santos EM, Workman VL, Paull GC, Filby AL, Van Look KJW, Kille P, Tyler CR: Molecular basis of sex and reproductive status in breeding zebrafish. Physiol Genomics 2007, 30(2):111-122.

90. Rinn $J$, Snyder M: Sexual dimorphism in mammalian gene expression. Trends Genet 2005, 21(5):298-305.

91. Reimers $M$, Heilig $M$, Sommer WH: Gene discovery in neuropharmacological and behavioral studies using Affymetrix microarray data. Methods 2005, 37(3):219-228

92. Palfreyman MT, Jorgensen EM: Roles of SNARE proteins in synaptic vesicle fusion. In Molecular Mechanisms of Neurotransmitter Release. Edited by Wang Z-W. Totowa, NJ: Humana Press; 2008:35-59.

93. Fujita $Y$, Shirataki H, Sakisaka T, Asakura T, Ohya T, Kotani H, Yokoyama S, Nishioka H, Matsuura Y, Mizoguchi A, et al: Tomosyn: A syntaxin-1-binding protein that forms a novel complex in the neurotransmitter release process. Neuron 1998, 20(5):905-915.

94. Scales SJ, Hesser BA, Masuda ES, Scheller RH: Amisyn, a novel syntaxinbinding protein that may regulate SNARE complex assembly. J Biol Chem 2002, 277(31):28271-28279.

95. Smirnova $\mathrm{T}$, Laroche $\mathrm{S}$, Errington ML, Hicks AA, Bliss TVP, Mallet J: Transsynaptic expression of a presynaptic glutamate receptor during hippocampal long-term potentiation. Science 1993, 262:433-436.

96. Kudryashova IV, Onufriev MV, Kudryashov IE, Gulyaeva NV: Regulation of cathepsin B and caspase-3 in long-term plasticity. Neurochemical Journal 2009, 3(4):260-266

97. Huesmann GR, Clayton DF: Dynamic role of postsynaptic caspase-3 and BIRC4 in zebra finch song-response habituation. Neuron 2006, 52: 1061-1072.

98. Hubert T, Grimal S, Carroll P, Fichard-Carroll A: Collagens in the developing and diseased nervous system. Cell Mol Life Sci 2009, 66:1223-1238.

99. Su J, Gorse K, Ramirez F, Fox MA: Collagen XIX is expressed by interneurons and contributes to the formation of hippocampal synapses. J Comp Neurol 2010, 518:229-253.

100. Biagioli M, Pinto M, Cesselli D, Zaninello M, Lazarevic D, Roncaglia P, Simone $R$, Vlachouli C, Plessy C, Bertin N, et al: Unexpected expression of $\alpha$ - and $\beta$ globin in mesencephalic dopaminergic neurons and glial cells. Proc Natl Acad Sci USA 2009, 106(36):15454-15459.

101. Richter F, Meurers BH, Zhu C, Medvedeva VP, Chesselet M-F: Neurons express hemoglobin a- and b-chains in rat and human brains. J Comp Neurol 2009, 515:538-547.

102. Whiteley AR, Bhat A, Martins EP, Mayden RL, Arunachalam M, Uusi-Heikkilä, Ahmed ATA, Shrestha J, Clark M, Stemple D, et al: Population genomics of wild and laboratory zebrafish (Danio rerio). Mol Ecol 2011, 20(20): 4259-4276.

103. Renn SCP, Aubin-Horth N, Hofmann HA: Fish and chips: functional genomics of social plasticity in an African cichlid fish. J Exp Biol 2008, 211:3041-3056.

104. Gentleman RC, Carey VJ, Bates DM, Bolstad B, Dettling M, Dudoit S, Ellis B, Gautier L, Ge Y, Gentry J, et al: Bioconductor: open software development for computational biology and bioinformatics. Genome Biol 2004, 5(10):R80.

105. R Development Core Team: R: A language and environment for statistical computing. Vienna, Austria: R Foundation for Statistical Computing; 2006

106. Bolstad BM, Irizarry RA, Astrand M, Speed TP: A comparison of normalization methods for high density oligonucleotide array data based on bias and variance. Bioinformatics 2003, 19(2):185-193.

107. Irizarry RA, Bolstad BM, Collin F, Cope LM, Hobbs B, Speed TP: Summaries of Affymetrix GeneChip probe level data. Nucleic Acids Res 2003, 31(4):e15. 
108. Irizarry RA, Hobbs B, Collin F, Beazer-Barclay YD, Antonellis KJ, Scherf U, Speed TP: Exploration, normalization, and summaries of high density oligonucleotide array probe level data. Biostatistics 2003, 4(2):249-264.

109. Gautier L, Cope L, Bolstad BM, Irizarry RA: affy-analysis of Affymetrix GeneChip data at the probe level. Bioinformatics 2004, 20(3):307-315.

110. Tusher VG, Tibshirani R, Chu G: Significance analysis of microarrays applied to the ionizing radiation response. Proc Natl Acad Sci USA 2001, 98(9):5116-5121.

111. Benjamini Y, Hochberg Y: On the adaptive control of the false discovery rate in multiple testing with independent statistics. Journal of Educational and Behavioral Statistics 2000, 25(1):60-83.

112. Gene Ontology Consortium: Gene Ontology: tool for the unification of biology. Nat Genet 2000, 25:25-29.

113. Drew RE, Rodnick KJ, Settles M, Wacyk J, Churchill E, Powell MS, Hardy RW, Murdoch GK, Hill RA, Robison BD: Effect of starvation on transcriptomes of brain and liver in adult female zebrafish (Danio rerio). Physiol Genomics 2008, 35(3):283-295.

doi:10.1186/1471-2164-13-323

Cite this article as: Drew et al.: Brain transcriptome variation among behaviorally distinct strains of zebrafish (Danio rerio). BMC Genomics 2012 13:323.

\section{Submit your next manuscript to BioMed Central and take full advantage of:}

- Convenient online submission

- Thorough peer review

- No space constraints or color figure charges

- Immediate publication on acceptance

- Inclusion in PubMed, CAS, Scopus and Google Scholar

- Research which is freely available for redistribution 